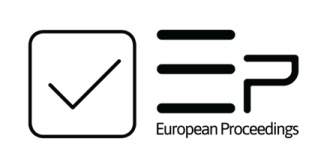

European Proceedings of

International Conference on Education \&

Educational Psychology

EPICEEPSY

www.europeanproceedings.com

e-ISSN: 2672-8141

DOI: $10.15405 /$ epiceepsy.21101.16

ICEEPSY 2021

$12^{\text {th }}$ International Conference on Education \& Educational Psychology

\title{
THE INTERPRETATION OF LITERARY TEXTS AT SECONDARY SCHOOLS
}

\author{
Alena Zachová (a)* \\ *Corresponding author \\ (a) University of Hradec Kralove, Faculty of Education, Rokitanskeho 62, 50003 Hradec Kralove, Czech Republic, \\ alena.zachova@uhk.cz
}

\begin{abstract}
The study examines the level of interpretation of literary fiction during literature lessons at contemporary Czech secondary schools. The ability to interpret text belongs to the basic requirements and key competencies of secondary school graduates. Research questions were related to the ability to interpret fiction texts. Via questionnaires, objective data, e.g., temporal orientation in period context, understanding of textual significance, and sense, were gathered. The research aimed to verify students' abilities to work creatively with contextual information, but mainly to infer the meaning of discussed literary texts. A qualitative research was conducted via a model test of literary competence aimed at graduating secondary school students and teachers. The findings of the test evaluation confirmed that students were able to navigate within texts and temporally classify texts correctly. However, students found difficulty in formulating the poetics of the given period as well as the meaning of the text. This shows that schools favour literary-historical perspectives over the understanding of the text.
\end{abstract}

2672-8141 @ 2021 Published by European Publisher.

Keywords: Literary fiction interpretation, secondary school curriculum requirements, teacher perceptions, test of literary competence 


\section{Introduction}

The present paper investigates the level of interpretation of fictional texts in literature classes in contemporary Czech secondary education. The teaching of literature at all school levels has always included, in addition to the transmission of knowledge of literary history and literary theory, work with fiction in a narrower sense, i.e. the analysis and interpretation of samples of texts. In this case, these documents are defined by curricula ${ }^{1}$ and defined by teaching programmes. The content of education, defined as a set of knowledge and skills, is then specified in textbooks, teacher's guides, didactic tests and school documents, through which the requirements are specified and implemented. The education system assumes that the values, attitudes and interests of pupils and students are also formed through knowledge and understanding.

The teaching of literature is based primarily on data and information about authors and literary works arranged in a literary canon that offers a selection of proven fiction texts. Nowadays, this canon is not fixed; we even speak of a plurality of canons, which is why the choice of selected texts is not strictly defined. However, the curricular framework is binding, which is why this research, focused on the interpretation of fiction texts in the context of teaching literature in secondary schools, focused on students' knowledge of the curricular areas covered and their ability to work creatively with the information and the texts themselves.

The ability to interpret a text (fiction or non-fiction/artistic or non-artistic) is one of the basic requirements and key competences of secondary school graduates. Interpretation of a fiction text is now also an important part of the Maturita exam. ${ }^{2}$ The structure of this examination is defined in the curriculum and includes the characterisation, analysis and interpretation of a fiction text at defined levels. In addition to the theme, students identify the composition, the literary type and genre, the lyrical subject, the characters of the text and the literary-historical context. The exam tests communication skills and the ability to interpret a fiction text appropriately. Therefore, this research focused only on upper grade students, specifically third and fourth year high school students. It investigated the relationship between factual or informational knowledge, such as authors, time period, artistic programs, etc., and the ability to draw one's own conclusions from the text itself. Although the requirements are clearly and precisely defined, it should be emphasized that literature works with fiction whose primary characteristic is ambivalence and polysemanticism (Ricœur \& Rejchrt, 1993). Therefore, when verifying especially the meaning of levels of texts, we must always keep in mind the level of subjective evaluation.

\section{Problem Statement}

The problem addressed by the research is related to the extent of the expository and factual part of the curriculum in secondary school literature classes and the extent of the curriculum devoted to the analysis of literary texts.

\footnotetext{
${ }^{1}$ For further reference, see http://www.nuv.cz/t/ramcove-vzdelavaci-programy-podle-kategorii-oboru-vzdelani.

${ }^{2}$ Available from http://www.novamaturita.cz/cesky-jazyk-a-literatura-1404033218.html.
} 
Although secondary schools do not currently use identical sets of textbooks, these textbooks do have common features. They are designed chronologically and, in addition to a wealth of explanatory information on literature and culture, also contain information on history, philosophy, sociology and technology. They are mainly factual in nature, enabling students to navigate themselves in the literary and social context of the time. The textbooks are often supplemented by various interesting facts, critical contemporary responses or text samples. Nevertheless, the teaching is still dominated by the interpretation of the material contained in the textbooks and handbooks, biographies and works of the authors, rather than by working with fiction texts themselves (Průcha, 2017). This research aimed to verify whether these facts, reflected in a number of studies, are still valid today, or whether it is possible to notice a change and a shift from factual information to interpretations of fiction in literature classes thanks to the newly set Framework Education Programmes and the newly designed Maturita exams in the Czech Republic.

\section{Research Question}

This research aimed to uncover if students are able to evaluate selected literary texts from a literary lens as well as from a factual aspect.

\section{Purpose of the Study}

According to a number of studies (Průcha, 2017; Ricœur \& Rejchrt, 1993), the teaching of literature in secondary schools is still dominated by teaching facts and information about the authors and the times in which they lived and worked, rather than working with the artistic texts themselves. The purpose of this research was to examine whether this trend in secondary schools has persisted or whether, due to changes in curriculum documents and changes in graduation requirements, there have been recent changes in favour of working with the text.

\section{Research Methods}

\subsection{Research design and sample}

The research design assumed the use of qualitative methods using a model test of literary competence and guided interviews with students and teachers of secondary schools in the Hradec Králové Region in the Czech Republic. The interviews were intended to supplement the information from the model test of literary competence and to broaden the survey with the opinions of all respondents. The investigation was conducted anonymously on a voluntary basis. Due the pandemic situation, the research was finally conducted online compared to the original plan. The evaluated sample included the answers of 21 students of $3^{\text {rd }}$ and $4^{\text {th }}$ grade of secondary schools of average age $17-18$ years and 11 teachers, of whom majority were women with an average age 50+ and period of teaching experience of 20 years and more.

\subsection{Research instruments}

A model test for third and fourth year high school students and questionnaires for their teachers. The model test of literary competence contained two sets of poetry texts, each set containing three poems. 
This genre was chosen mainly because of the volume of the texts; the selected samples were not extensive and the students were able to navigate through the text relatively quickly and clearly.

The first set contained excerpts from Czech poetry of the late 19th century; the texts did not include the author's name or the time of their composition. The questions tested whether students could identify the author from the text and whether they could identify the period of their composition (not the year, but the period, i.e. the first or second half of the 19th century) from the characteristic features of the period poetics. Another question was also directed to the poetics of the texts; students were asked to select from the examples the features and motifs that were defining for the poetry of that period. A question ascertaining the students' factual knowledge was aimed at naming three authors of poetry of the first and second half of the 19th century and the first and second half of the 20th century.

The second set also contained three short samples of poetry, this time from the early 20th century, and the questions were of the same character as those in the first set; part of the questions tested the students' factual knowledge - their knowledge of contemporary authors, the other part ascertained whether the students were able to identify the features and characteristics of the poetics of the period through texts whose authors were not mentioned by name in the test.

The questionnaire for teachers was used to identify teachers' perceptions to what extent they thought students were able to correctly answer the fact-checking questions and the knowledge-checking questions through textual study.

\subsection{Research process}

The model test of the literary competence survey was supposed to take place in the spring of 2020 . However, due to the outbreak of Covid-19, all schools in this country were closed as of March 2020, so the implementation of the survey was postponed to the autumn of 2020, although the schools remained closed until the spring of 2021. The guided interviews had to be omitted due to the lockdown constraints. Of the 60 tests sent out to the students; only 21 completed tests were returned, and of the 30 questionnaires for teachers; only 11 completed questionnaires were returned which is a response rate of about $35 \%$. The response rate is not ideal but, given the circumstances of the pandemic, it was decided to proceed with the study so as not to waste the data collected and not to incur more delay in getting on with the study.

\section{Findings}

The model test of literary competence contained two types of questions. As expected, the students were more successful at answering the factual questions, but it can also be stated that the more difficult questions focused on the contemporary poetics of the selected authors and texts had a certain success rate.

The highest number of correct answers related to questions in which students were asked to match verses from the test to different periods of the 19th and 20th centuries, and to write the names of three poets for each period (the average success rate of questions related to the 19th century was over $70 \%$, and questions related to the 20th century showed a $30 \%$ success rate). The number of correct answers to the question in which students were asked to assign authors to the poems of both sets, i.e. to three 19th century texts and three 20 th century texts, attained $57 \%$. 
Answers to questions aimed at determining the temporal and programmatic placement of texts from inferring characteristic features, motifs and contemporary poetics were, as expected, less successful. Motifs and typical features were correctly identified by $57 \%$ of students again for 19th century poetry and only $28 \%$ for poetry of the early 20 th century.

It is clear from the responses that 19th century poetry and literature in general is more familiar and clear to students, whereas modern poetry, based on free verse and metaphorical modes of expression, is more difficult.

The teachers' reactions, which were generally interesting, showed that they had guessed quite accurately which questions would be easier and which would be more difficult for the students. Their responses included;

"I think they recognized Hálek by the singers and the patriotic mood.";

"This kind of poetry usually attracts them and they are open to it."

"I think they should be able to identify the typical characters." “

"Firstly, we explain the substance theoretically, then we prove it by reading the samples. I have my databank of texts that correspond to the main characters of the directions and styles."

"Even when we discuss the authors mentioned, I think they are not able to recognize them from the texts."

"We mention all the authors, but we don't devote significant space to their work. The class is dominated by boys who are not interested in reading poetry from this period."

It is clear from the responses that secondary schools do after all regularly work with fiction texts in literature classes, although differences between schools certainly remain. It is also clear from the findings which periods and what type of literature would benefit from more time and space.

\section{Discussion and Conclusion}

Interpretation, whether we call it exegesis, explanation or interpretation, is always an intellectual activity that forms a generally important part of thinking and makes certain knowledge and personal demands on every interpreter (Lederbuchová, 2007). Traditionally understood literary theoretical interpretation has been concerned mainly with the external, causal relations and dependencies of literary works on their literary context. Today, the interpretation of a text is shifting more toward an examination of the internal meanings and contexts necessary to understand the text in its multi-layered sense. As, for example, Eco and Fiala (2000) argue, the final interpretation is always the result of a complex interaction involving as much the competence potential of the reader as the competence postulated by the fiction text itself.

It is obvious from the very nature of the meaning of interpretation that it is a largely subjective and individual activity, which is why there are always attempts to re-specify or re-formulate this activity in school teaching (Stuchlíková et al., 2015). There is a regular need to adjust the proportions between literary history or theory of literature and the actual work with specific fiction texts. According to Hník (2014), the literary-historical perspective still prevails in schools over knowledge of the text and knowledge of the context over the texts themselves. He also points to the important fact that it is the personality of the teacher and their methods that matter more than the choice of the appropriate text. 
This investigation confirmed the improvement in the sub-results, with students being able to navigate the texts for more than half of the given sample. Formulating the poetics of a given time period is indeed challenging and most students cannot be expected to be successful in this aspect of literary criticism.

It seems that the formal organization of curriculum documents and graduation requirements in favour of working with a specific text in high school literature classes is currently sufficient. The interpretive component of teaching needs to be cultivated and the validation of new practices is an ongoing task; teaching and education in general is a process that never ends.

\section{Acknowledgments}

The contribution is financially supported by a grant of the Specific research of the Faculty of Education of the University of Hradec Kralove (No. 2119/01310/1210).

\section{References}

Eco, U., \& Fiala, J. (Eds.) (2000). Mysl a smysl: sémiotický pohled na svět [Mind and sense: a semiotic view of the world]. Moraviapress.

Hník, O. (2014). Didaktika literatury: výzvy oboru: od texti̊ umělecké povahy $k$ didaktice estetickovýchovného oboru [Didactics of literature: challenges of the field: from texts of an artistic nature to the didactics of aesthetics education]. Karolinum.

Lederbuchová, L. (2010). Literatura ve škole: četba žáka a didaktická interpretace uměleckého textu v literární výchově na 2. stupni základni školy a v odpovídajicich ročnícich víceletého gymnázia [Literature in school: pupil reading and didactic interpretation of art text in literary education and the $2^{\text {nd }}$ level of primary school and in corresponding years of the multi-year grammar school]. Západočeská univerzita v Plzni.

Průcha, J. (2017). Moderní pedagogika [Modern pedagogy]. Portál.

Ricœur, P., \& Rejchrt, M. (Eds.) (1993). Život, pravda, symbol [Life, truth, symbol]. OIKOYMENH.

Stuchlíková, I., Janík, T., Beneš, Z., Bílek, M., Brücknerová, K., Černochová, M., Čížková, V., Čtrnáctová, H., Dvořák, L. Dytrtová, K., Gracová, B., Hník, O., Kekule, M., Kostková, K., Kubiatko, M., Nedělka, M., Novotná, J., Papáček, M., Petr, J., ... Žák, V. (2015). Oborové didaktiky: vývoj, stav, perspektivy [Subject didactics: development, state, perspective]. Masarykova univerzita. https://doi.org/10.5817/CZ.MUNI.M210-7884-2015 